\section{Package design and nutritional profile of foods targeted at children in supermarkets in Montevideo, Uruguay}

\author{
Desenho das embalagens e perfil nutricional \\ de alimentos dirigidos ao público infantil em \\ supermercados em Montevidéu, Uruguai
}

\section{Diseño de envase y perfil nutricional de alimentos dirigidos a niños disponibles en supermercados en Montevideo, Uruguay}

Ana Giménez 1

Luis de Saldamando 1

María Rosa Curutchet 2

Gastón Ares 1

doi: 10.1590/0102-311X00032116

\begin{abstract}
Marketing of unhealthy products has been identified as one of the main characteristics of the food environment that negatively affects children's eating patterns. Restrictions on advertising of unhealthy foods to children have already been imposed in different countries. However, marketing strategies are not limited to broadcast and digital advertising, but also include package design. In this context, the current study aimed to describe the food products targeted at children and sold in supermarkets in Montevideo, Uruguay, in terms of package design and nutrient profile. Two supermarkets in Montevideo were selected for data collection. In each supermarket, all products targeted at children were identified. Products were analyzed in terms of package design and nutritional profile, considering the Pan American Health Organization Nutrient Profile Model. A total of 180 unique products were identified, which included a wide range of product categories. The great majority of the products corresponded to ultra-processed products with excessive amounts of sodium, free sugars, total fat, saturated fat, and/or trans fat, which are not recommended for frequent consumption. Several marketing strategies were identified in the design of packages to attract children's attention and drive their preferences. The most common strategies were the inclusion of cartoon characters, bright colors, childish lettering, and a wide range of claims related to health and nutrition, as well as the products' sensory and hedonic characteristics. The study's findings provide additional evidence on the need to regulate packaging of products targeted at children.
\end{abstract}

Food Packaging; Food Composition; Food Publicity; Child

\author{
Correspondence \\ G. Ares \\ Instituto Polo Tecnológico de Pando, Facultad de Química, \\ Universidad de la República. \\ By Pass de Rutas 8 y 101 s/n, Pando, Canelones 91000, \\ Uruguay. \\ gares@fq.edu.uy \\ 1 Facultad de Química, Universidad de la República, Canelones, \\ Uruguay. \\ 2 Instituto Nacional de Alimentación, Montevideo, Uruguay.
}




\section{Introduction}

Childhood overweight and obesity have increased at an alarming rate in the last decades, affecting more than 170 million children under the age of 18 worldwide 1 . Although the majority of these children live in upper-middle income countries, the prevalence of overweight and obesity in low and middle income countries is showing the fastest growth rate 2 . In the specific case of Latin America, it has been estimated that $20-25 \%$ of children and adolescents are overweight or obese 3 . Uruguay is among the countries with the highest prevalence of overweight and obesity in Latin America, particularly among children under 4 years of age (10.5\%) 4 .

Childhood overweight and obesity are associated with various health problems and increased risk of premature onset of non-communicable diseases such as diabetes and cardiovascular disease, which lead to a reduction in quality of life and life expectancy 5,6,7. This situation makes childhood obesity one of the most important public health challenges worldwide and stresses the need to urgently develop population-based strategies to cope with the global epidemic 1 .

According to Hawkes et al. 8 , effective public policies should take into account the interaction between food preferences and the environment. The environment in which children are born and raised can contribute to their risk of becoming overweight and obese 2 . In this sense, changes in the global food system have increased the availability of highly processed products with high sugar, salt, and fat content, such as candy, soft drinks, snacks, and fast food 9,10. Consumption of these products has been associated directly with obesity and other non-communicable diseases 11,12,13,14,15.

Marketing of unhealthy products has been identified as one of the main characteristics of the food environment that negatively contributes to children's food preferences and dietary patterns by encouraging consumption of products with high fat, sugar, and salt content 16,17,18,19. According to reports, a considerable share of food companies' advertising budget is spent on advertisements targeted at children through TV, radio, the internet, and magazines 16,20,21. Therefore, restrictions on advertising of unhealthy foods to children have been recommended and have already been imposed in different countries 2,18,19. However, marketing strategies are not limited to broadcast and digital advertising, but also include packaging, sponsorship, and merchandising 20.

The contribution of package design to the marketing of food products targeted at children has increased in recent years 22. Package design plays a major role in attracting attention and influencing purchase intent, and provides food companies the last chance to persuade consumers to buy the product at the point of sale 23 . Foods targeted at children are usually marketed using unconventional flavor and colors, cartoon characters, photos of celebrities, household names, merchandising tie-ins, and direct references to fun and play on the packages 22,24,25,26. These marketing strategies have been reported to encourage children to think that products are tastier, healthier, funnier, and more appropriate for them, increasing their liking and willingness to consume 27,28.

Thus, regulation of labelling thus seems necessary to encourage children to avoid consumption of unhealthy products 22 . Implementation of such regulation requires detailed identification of the strategies used by food companies to promote products targeted at children and evaluation of their impact on children's perception and food choices. However, few studies have analyzed the characteristics of products targeted at children in Latin American countries, thus calling for further studies on the topic 24,29 .

In this context, the current study aimed to describe the products targeted at children sold in supermarkets in Montevideo, Uruguay, in terms of package design and nutrient profile.

\section{Methodology}

\section{Sampling and data collection}

Two of the most widespread and popular supermarkets in Montevideo, the capital city of Uruguay, were selected for data collection. In each supermarket, three researchers participated in the survey to ensure that all relevant products were identified. Data collection was carried out in October 2014. 
All products targeted at children were identified according to the following criteria, previously addressed by other authors 24,26: (a) direct references to children; (b) use of cartoon characters; (c) unusual package/product shape or color; (d) references to sports, TV programs, or movies; and (e) premium offers and promotions targeted at children (collectibles, raffles). Products were analyzed on site and photographed.

Products that were sold in both supermarkets were included only once in the product sample. Besides, when several products of the same brand but differing only in flavor or package size were found, only one one of them was included in the analysis. Considering that the products had identical package characteristics and nutritional composition, the product included in the analysis was randomly selected.

\section{Data analysis}

The following information was obtained from each of the identified products: food category, brand, product name, package characteristics (color, use of cartoon characters, use of images), nutritional information (calories, total fat, saturated fat, trans fat, sugar, salt), ingredients, promotions, links to sports, TV programs, or movies, and claims (nutritional claims, product usage, references to fun, and other benefits).

The information described above was coded in categories using inductive coding by three of the study's authors. The number of products in each category was determined at the aggregate level and for each of the identified product categories. Significant differences in the frequency of the categories were evaluated using the chi-square test. A chi-square per cell test was used to identify the source of variation of the global chi-square.

According to their ingredients and nutritional composition, products were classified according to the Pan American Health Organization Nutrient Profile Model 30. This profile is limited to processed and ultra-processed products, as they normally contain high added sodium, sugar, total fat, saturated fat, and trans fat content. Free sugars were estimated following the recommendations proposed in the model 30 .

\section{Results}

A total of 180 unique products were identified as targeted at children, which were classified in nine main categories (Table 1). The most common category was candy and chocolates, followed by cookies and pastries, dairy products, and breakfast cereals. These four categories accounted for $77 \%$ of the products. The category "other" comprised three different products: fruit puree, mayonnaise, and salami.

The identified products met between 1 and 5 of the criteria for classifying a product as targeted at children (average of 2 criteria). The inclusion of cartoon characters on food packages was the most common strategy, used by $76 \%$ of the products, followed by unusual package/product shape or color, found in $74 \%$ of the products. The other three criteria were used less frequently: direct references to children (26\%), offers and promotions targeted at children (22\%), and references to sports, TV programs, or movies (17\%).

\section{Package characteristics}

Table 2 shows an overview of the package characteristics of the identified products. Marketing strategies related to package and label design were frequently used, particularly bright colors, cartoon characters, and childish fonts on the labels. Some products also included explicit references to children through text or pictures, as well as references to fun (Table 2).

Significant differences in the frequency of use of the categories among product categories were identified $(\mathrm{p}<0.001)$. For example, products in the candy and chocolate category frequently used bright colors and unusual package shape, while unusual product shape was common in frozen readyto-eat products such as animal-shaped nuggets (Table 2). 


\section{Table 1}

Number of products targeted at children in nine food categories identified in two supermarkets in Montevideo, Uruguay.

\begin{tabular}{lcc}
\hline Product category & Number of products & Percentage of the total (\%) \\
\hline Candy and chocolate & 45 & 25 \\
Cookies and pastries & 37 & 21 \\
Dairy products & 33 & 18 \\
Breakfast cereals & 24 & 13 \\
Instant food & 17 & 9 \\
Soft drinks and juices & 9 & 5 \\
Savory snacks & 8 & 4 \\
Frozen ready-to-eat foods & 4 & 2 \\
Other * & 3 & 2 \\
Total & 180 & 100 \\
\hline
\end{tabular}

* This category included a meat product (salami), a fruit puree, and a mayonnaise.

Table 2

Percentage of products targeted at children with different package characteristics.

\begin{tabular}{|c|c|c|c|c|c|c|c|c|c|c|}
\hline \multirow[t]{2}{*}{ Characteristic } & \multicolumn{10}{|c|}{ Percentage of products in each category (\%) } \\
\hline & Total & 1 & 2 & 3 & 4 & 5 & 6 & 7 & 8 & 9 \\
\hline Package design * & 66 & 87 & 51 & 52 & 75 & 41 & 56 & 100 & 100 & 33 \\
\hline Bright colors * & 66 & 87 & 51 & 52 & 75 & 41 & 56 & 100 & 100 & 33 \\
\hline Unusual shape * & 8 & 22 & 0 & 6 & 0 & 6 & 0 & 0 & 0 & 33 \\
\hline References to unusual product shape/color * & 8 & 11 & 5 & 6 & 13 & 0 & 11 & 0 & 50 & 0 \\
\hline Cartoon characters & 76 & 62 & 70 & 70 & 96 & 88 & 89 & 88 & 75 & 100 \\
\hline Generic character & 61 & 44 & 57 & 67 & 67 & 82 & 56 & 88 & 50 & 100 \\
\hline Licensed character * & 14 & 18 & 14 & 3 & 29 & 6 & 33 & 0 & 25 & 0 \\
\hline Childish lettering & 57 & 64 & 59 & 45 & 75 & 47 & 56 & 13 & 100 & 33 \\
\hline References to children * & 26 & 13 & 35 & 48 & 13 & 12 & 22 & 13 & 50 & 33 \\
\hline Textual reference to children * & 20 & 11 & 30 & 36 & 4 & 6 & 22 & 13 & 50 & 33 \\
\hline Picture of children * & 6 & 2 & 5 & 12 & 8 & 6 & 0 & 0 & 0 & 0 \\
\hline References to fun & 26 & 20 & 38 & 33 & 25 & 24 & 0 & 13 & 0 & 33 \\
\hline Cross-advertisement * & 12 & 4 & 22 & 0 & 17 & 35 & 0 & 13 & 0 & 0 \\
\hline References to the brand/Product website * & 7 & 4 & 22 & 0 & 0 & 6 & 0 & 13 & 0 & 0 \\
\hline References to the company website * & 7 & 0 & 8 & 0 & 17 & 35 & 0 & 0 & 0 & 0 \\
\hline Tie-ins * & 17 & 16 & 14 & 18 & 13 & 35 & 11 & 13 & 25 & 0 \\
\hline Movies/TV programs * & 9 & 16 & 16 & 0 & 13 & 0 & 0 & 0 & 25 & 0 \\
\hline Sports * & 7 & 0 & 3 & 18 & 0 & 35 & 11 & 13 & 0 & 0 \\
\hline Promotions targeted at children & 27 & 16 & 41 & 18 & 46 & 41 & 0 & 0 & 25 & 0 \\
\hline Games/Puzzles on the package * & 14 & 7 & 8 & 6 & 46 & 35 & 0 & 0 & 25 & 0 \\
\hline Toys/Prizes & 8 & 9 & 11 & 12 & 0 & 6 & 0 & 0 & 0 & 0 \\
\hline Online contests * & 4 & 0 & 22 & 0 & 0 & 0 & 0 & 0 & 0 & 0 \\
\hline Price promotions & 4 & 2 & 8 & 6 & 0 & 0 & 0 & 13 & 0 & 0 \\
\hline 2 for $1 *$ & 1 & 0 & 0 & 3 & 0 & 0 & 0 & 0 & 0 & 0 \\
\hline Larger package at reduced price & 3 & 2 & 8 & 3 & 0 & 0 & 0 & 13 & 0 & 0 \\
\hline
\end{tabular}

* Indicates package characteristics for which significant differences among product categories were identified according to the chi-square per cell test $(p<0.05)$.

Note: categories: 1 - candy and chocolate; 2 - cookies and pastries; 3 - dairy products; 4 - breakfast cereals; 5 - instant food; 6 - soft drinks and juices; 7 - savory snacks; 8 - frozen ready-to-eat foods; 9 - other. 
The products included cross-advertisement or merchandising, or references to the brand/product or company website. This marketing strategy was more common in three categories: breakfast cereals, instant food, and cookies and pastries (Table 2). Tie-ins with movies, TV programs, and sports were also found in several products. In particular, tie-ins with sports were common in the instant food category.

Promotions targeted at children were found in $27 \%$ of the products. The main type of promotion used by food companies was the inclusion of games/puzzles on the packages, especially in three categories: breakfast cereals, instant food, and frozen ready-to-eat foods (Table 2). Food packages also contained prizes such as toys, stickers, and pencil cases. Besides, 22\% of the cookies and pastries included references to online contests on the package.

Price promotions were also identified, although in a small proportion of products. Promotions included selling the second or selling product a larger package at a reduced price in four categories: candy and chocolate, cookies and pastries, dairy products, and savory snacks.

A wide range of claims were included on the packages, as shown in Table 3. At the aggregate level, health/nutrition claims were the most frequent on products targeted at children. However, differences in the frequency of use of such claims across product categories were found. As shown in Table 3 , health/nutrition claims were markedly more frequent in breakfast cereals and soft drinks and juices than in the other categories. Claims about supplemented vitamins and minerals were the most frequent, and were found only in five categories: cookies and pastries, dairy products, breakfast cereals, instant food, and soft drinks and juices. Besides, claims about healthfulness/nutrition energy were only included on breakfast cereal packages. Other health and nutrition claims included references to energy, absence of trans fat, and inclusion of probiotics (Table 3).

\section{Table 3}

Percentage of the products targeted at children, identified in two supermarkets in Montevideo, Uruguay, including different claims.

\begin{tabular}{|c|c|c|c|c|c|c|c|c|c|c|}
\hline \multirow[t]{2}{*}{ Type of claim } & \multicolumn{10}{|c|}{ Percentage of products in each category (\%) } \\
\hline & Total & 1 & 2 & 3 & 4 & 5 & 6 & 7 & 8 & 9 \\
\hline Health/Nutrition claims * & 19 & 0 & 3 & 24 & 54 & 29 & 56 & 13 & 25 & 33 \\
\hline Added minerals * & 14 & 0 & 0 & 18 & 46 & 29 & 33 & 0 & 0 & 0 \\
\hline Added vitamins * & 14 & 0 & 3 & 18 & 46 & 18 & 44 & 0 & 0 & 0 \\
\hline References to healthfulness/Nutrition * & 5 & 0 & 0 & 0 & 33 & 0 & 0 & 0 & 0 & 0 \\
\hline References to energy & 3 & 0 & 0 & 3 & 8 & 0 & 11 & 0 & 0 & 33 \\
\hline No trans fat *,** & 2 & 0 & 0 & 0 & 4 & 0 & 0 & 13 & 25 & 0 \\
\hline Probiotics * & 1 & 0 & 0 & 6 & 0 & 0 & 0 & 0 & 0 & 0 \\
\hline Ingredient claims * & 12 & 16 & 3 & 21 & 0 & 0 & 33 & 0 & 50 & 33 \\
\hline Gluten-free * & 8 & 4 & 0 & 18 & 0 & 0 & 33 & 0 & 50 & 33 \\
\hline No colorings * & 3 & 7 & 3 & 0 & 0 & 0 & 0 & 0 & 0 & 33 \\
\hline No flavorings * & 3 & 9 & 0 & 0 & 0 & 0 & 0 & 0 & 0 & 33 \\
\hline No preservatives & 2 & 2 & 3 & 3 & 0 & 0 & 11 & 0 & 0 & 0 \\
\hline Other claims * & 18 & 11 & 22 & 12 & 33 & 6 & 22 & 25 & 0 & 100 \\
\hline Naturalness & 1 & 0 & 0 & 0 & 4 & 0 & 0 & 0 & 0 & 0 \\
\hline Sensory (tasty/delicious/crunchy) * & 13 & 4 & 22 & 9 & 29 & 6 & 0 & 25 & 0 & 33 \\
\hline Ideal for snacking * & 1 & 0 & 0 & 3 & 0 & 0 & 0 & 0 & 0 & 33 \\
\hline References to fruit * & 3 & 7 & 0 & 0 & 0 & 0 & 22 & 0 & 0 & 33 \\
\hline
\end{tabular}

* Indicates claims for which significant differences among product categories were identified according to the chi-square per cell test $(p<0.05)$;

** The trans fat content of dairy products was not considered in the classification.

Note: categories: 1 - candy and chocolate; 2 - cookies and pastries; 3 - dairy products; 4 - breakfast cereals;

5 - instant food; 6 - soft drinks and juices; 7 - savory snacks; 8 - frozen ready-to-eat foods; 9 - other. 
Claims about absence of specific ingredients were included on $12 \%$ of the product packages, mainly related to additives (colorings, flavorings, and preservatives). These claims were mainly found in three categories: candy and chocolate, cookies and pastries, and the other products category (Table 3). Gluten-free claims were also found on some packages, particularly in dairy products, soft drinks and juices, and frozen ready-to-eat-products.

Other claims were also identified on the packages, as shown in Table 3. The most common claim emphasized the products' sensory and hedonic characteristics, such as tastiness, deliciousness, or distinct sensory characteristics (e.g. crunchy). Such claims were common in cookies and pastries, breakfast cereals, savory snacks, and one product in the others category (salami) (Table 3). Other claims stressed product naturalness (ideal for snacking) or referred to fruits, although at the aggregate level they were less common than the other claims.

\section{Nutrient profile}

The great majority of products targeted at children and identified in the current study were classified as ultra-processed (97\%). The remaining products (five, or 3\%) corresponded to unprocessed or minimally processed products (sunflower seeds, pasteurized milk, and powdered milk).

All the ultra-processed products identified in the study were included in at least one of the categories of the Pan American Health Organization Nutrient Profile Model 30, indicating that they all contained excessive amounts of sodium, free sugars, total fat, saturated fat, and/or trans fat and/or contained artificial sweeteners. Products were included in an average of 2.0 categories. However, some products were included in only one category, whereas others were included in four. Most products contained excessive amounts of free sugars (Table 4), which represented more than 10\% of their total energy content 29 . The majority of the savory products, particularly savory snacks and frozen ready-to-eat foods, also contained excessive amounts of sodium. The least frequent category related to ultra-processed products formulated with sweeteners, as only one of the products (soft drinks) fit this description.

As expected, the study identified differences in the nutrient profile of product categories (Table 4). Cookies and pastries were included in an average of 3.5 categories in the Nutrient Profile Model, indicating that they contained excessive amounts of three to four nutrients. As shown in Table 4, the great majority of products in this category contained excessive amounts of free sugars, total fat, and saturated fat, while $62 \%$ of the products also contained excessive amounts of trans fat.

Dairy products and savory snacks were classified in an average of 2.2 categories in the Nutrient Profile Model, indicating that they contained excessive amounts of two nutrients on average. As shown in Table 4, dairy products frequently contained excessive amounts of sugar and saturated fat, while most savory snacks contained excessive amounts of sodium and total fat.

\section{Discussion}

In the current study, a wide range of product categories targeted at children were identified in two supermarkets in Montevideo, Uruguay. The most common categories were candy and chocolate, cookies and pastries, dairy products, and breakfast cereals. The products were not only limited to snack foods but included products suitable for different eating occasions, including breakfast and main meals. Marketing of such a diverse range of products for children may convey the idea that they should eat different foods than adults, as previously highlighted by Elliot 28 .

The great majority of products corresponded to ultra-processed products with excessive amounts of sodium, free sugars, total fat, saturated fat, and/or trans fat, not recommended for frequent consumption 20. These findings corroborate other studies conducted in different countries, which have classified child-oriented products as unhealthy 24,26,29,31,32. Consumption of highly processed foods or ultra-processed products has been associated with obesity and other non-communicable diseases, even in children 11,12,14,33. Sales of frozen products, cookies, snacks, candy, ice cream, and soft drinks have increased markedly in the last 10 years in several Latin American countries 14. In particular, 
Table 4

Percentage of products targeted at children, identified in two supermarkets in Montevideo, Uruguay, classified in each of the food groups defined by the Pan American Health Organization Nutrient Profile 30.

\begin{tabular}{lccccccccccc}
\hline & \multicolumn{10}{c}{ Percentage of products in each category (\%) } \\
& Total & $\mathbf{1}$ & $\mathbf{2}$ & $\mathbf{3}$ & $\mathbf{4}$ & $\mathbf{5}$ & $\mathbf{6}$ & $\mathbf{7}$ & $\mathbf{8}$ & $\mathbf{9}$ \\
\hline Unprocessed or minimally processed * & 3 & 0 & 0 & 12 & 0 & 0 & 0 & 11 & 0 & 0 \\
Ultra-processed foods * & 97 & 100 & 100 & 88 & 100 & 100 & 100 & 89 & 100 & 100 \\
Excessive amount of sodium * & 17 & 0 & 0 & 7 & 50 & 6 & 22 & 86 & 75 & 33 \\
Excessive amount of free sugars * & 91 & 100 & 100 & 100 & 92 & 94 & 89 & 14 & 0 & 33 \\
Contain sweeteners * & 1 & 0 & 0 & 0 & 0 & 0 & 11 & 0 & 0 & 0 \\
Excessive amount of total fat * & 40 & 33 & 95 & 21 & 4 & 0 & 0 & 86 & 75 & 67 \\
Excessive amount of saturated fat * & 50 & 36 & 97 & 86 & 4 & 6 & 0 & 43 & 50 & 67 \\
Excessive amount of trans fat * & 14 & 2 & 62 & $0 * *$ & 0 & 0 & 0 & 25 & 0 & 0
\end{tabular}

* Indicates that differences among product categories were significant according to the chi-square per cell test $(p<0.05)$; ** The trans fat content of dairy products was not considered in the classification.

Note: categories: 1 - candy and chocolate; 2 - cookies and pastries; 3 - dairy products; 4 - breakfast cereals; 5 - instant food; 6 - soft drinks and juices; 7 - savory snacks; 8 - frozen ready-to-eat foods; 9 - other. Percentages within the ultraprocessed foods category do not total exactly $100 \%$ because each product could be included in more than one category of the Pan American Health Organization Nutrient Profile.

consumption of these products in Uruguay has increased 68.4\% between 2000 and 2013, in parallel with a marked increase in the prevalence of overweight and obesity 14,34 .

Most products targeted at children were ultra-processed, which raises concerns about children becoming accustomed to such foods and losing the ability to appreciate the value of natural and homemade food 28. It thus appears necessary to regulate marketing of ultra-processed products as appropriate foods for children 18. Educational campaigns to discourage children and their parents from consuming such products are also advisable 14 .

Food companies have used various marketing strategies in package design to attract children's attention and drive their preferences. The most common strategy was the inclusion of cartoon characters, as well as tie-ins with movies, TV, and sports, although less frequently. Children have been reported to create emotional bonds with familiar characters that encourage them to consume products associated with them $27,35,36,37$. In the current study, licensed characters were markedly less frequent than generic characters, probably due to the cost associated with using licensed characters. This trend has been also reported by Chacon et al. ${ }^{24}$ when analyzing snack foods for children in Guatemala. Importantly, unfamiliar cartoon characters can be as effective as familiar ones in increasing children's positive hedonic reaction to products 38 .

Other frequently identified design strategies were the use of bright colors, unusual shapes, and childish fonts, aimed at attracting children's attention to the packages. Package color and shape also create sensory and hedonic expectations that can drive preferences and have a large impact on food choices 39,40 .

Packages also included references to fun, as well as promotions involving games, puzzles, toys, and other prizes, as reported by other authors 18,19,24,26. This strategy may induce children to create a problematic relationship with foods, as they learn to frame foods as entertainment rather than contributing to their health and wellbeing 26 . Other promotions involved product discounts, targeted at parents, but were less frequent than those targeted at children.

Products made a wide range of claims on the packages, most related to health and nutrition. The inclusion of such claims has been reported to influence the perception of healthfulness, as well as hedonic expectations of school-aged children 41,42 . Nutrition claims have also been reported to influence parents, who usually base their healthfulness judgments of products on nutrition claims rather 
than on an exhaustive evaluation of the nutritional information included on the packages 43 . In the current study, all products with health and nutrition claims contained excessive amounts of at least one of several nutrients that have been associated with negative health outcomes 20 . Similar results have been reported by other authors, stressing that nutrition claims on food packages and marketing campaigns are commonly used by food companies to convey the concept of healthfulness in products that are high in sugar, saturated fat, and/or sodium 44. Therefore, claims related to health and nutrition can mislead parents and have a negative impact on the nutritional composition of the packaged food products selected by parents for their children. Strict regulations on the use of nutrition claims on packages of products targeted at children are thus necessary. In this sense, nutrient profiling tools to determine the eligibility of foods to display health and nutrition claims should be developed in Latin American countries, as previously implemented in Australia and New Zealand 45.

Finally, it is important to highlight that some products made claims related to naturalness, as well as lack of colorings, flavorings and preservatives, which may also induce healthful associations by children and parents. The use of claims related to naturalness is particularly relevant in light of the increased importance attributed to processed products in the global obesity epidemic 14,15,30. Therefore, regulation of such claims on food packages and advertising is also advisable.

In closing, it is important to address some of the study's potential limitations. First, only products sold at two supermarkets in Montevideo were analyzed, which does not provide a representative overview of products targeted at children and available in Uruguay as a whole. Although products available at other supermarket chains may be similar to those identified in the present study, further research should also consider products sold at convenience stores and other informal stores located in different neighborhoods. It would be interesting to compare differences between products targeted at children and available in neighborhoods with different income levels. In this study, sampling was done at a single point in time, which does not provide an overview of how the products' characteristics change throughout the year, or particularly in relation to special events such as Christmas or Easter. Despite such limitations, the study provides a comprehensive analysis of the characteristics of products targeted at children available in Uruguay and is the first study to apply the Pan American Nutrient Profile Model to analyze the nutritional composition of such products.

\section{Conclusions}

The contribution of advertising unhealthy products to the global childhood obesity epidemic has been recognized, and various countries have implemented regulations 18 . However, the contribution of package design to the marketing of child-oriented products has still not been fully acknowledged. The current study's results provide additional evidence of the nutrient profile of products targeted at children, as well as the wide range of strategies related to package design frequently used by the food industry to market their products. Considering that self-regulation has proven unsuccessful 18, it is necessary to strictly regulate package design and product shape of products targeted at children, with particular emphasis on the use of cartoon characters and health/nutrition claims. Records of such regulation exist in anti-tobacco campaigns, as companies have been forced to remove all logos and images from packages 46. Although this type of regulation may be excessive, the relevance of package design on children's perception of food products should be acknowledged in public policies 18. In this sense, additional empirical evidence of the extent to which package design influences children's preferences and perception of healthfulness is needed to support the development of appropriate and effective public policies. 


\section{Contributors}

A. Giménez participated in the study design and implementation, data analysis, and writing of the article. L. Saldamando participated in the study design and implementation and data analysis. M. $\mathrm{R}$. Curutchet participated in the study design and writing of the article. G. Ares participated in the study design and implementation, data analysis, and writing of the article. All authors approved the final version of the paper for publication.

\section{Acknowledgments}

The authors are indebted to Comisión Sectorial de Investigación Científica Espacio Interdisciplinario (Universidad de la República, Uruguay) for financial support.

\section{References}

1. Lobstein T, Baur L, Uauy R. Obesity in children and young people: a crisis in public health. Obes Rev 2004; 5:4-104.

2. World Health Organization. Population-based approaches to childhood obesity prevention. Geneva: World Health Organization; 2012.

3. Rivera JA, de Cossío TG, Pedraza LS, Aburto TC, Sánchez TG, Martorell R. Childhood and adolescent overweight and obesity in Latin America: a systematic review. Lancet Diabetes Endocrinol 2014; 2:321-32.

4. Cabella W, Rosa M, Failache E, Fitermann P, Katzkowicz N, Medina M, et al. Encuesta Nacional de Salud, Nutrición y Desarrollo Infantil. Montevideo: Oficina de Planeamiento y Presupuesto/Uruguay Crece Contigo; 2015.

5. Ezzati M, Lopez AD, Rodgers A, Murray CJL. Comparative quantification of health risks: global and regional burden of disease attributable to selected major risk factors. Geneva: World Health Organization; 2004.

6. Tsiros MD, Olds T, Buckley JD, Grimshaw P, Brennan L, Walkley J, et al. Health-related quality of life in obese children and adolescents. Int J Obes 2009; 33:387-400.

7. Williams J, Wake M, Hesketh K, Maher E, Waters E. Health-related quality of life of overweight and obese children. JAMA 2005; 293:70-6.

8. Hawkes C, Smith TG, Jewell J, Wardle J, Hammond RA, Friel S, et al. Smart policies for obesity prevention. Lancet 2015; 385:2410-21.

9. Popkin BM, Adair LS, Ng SW. Global nutrition transition and the pandemic of obesity in developing countries. Nutr Rev 2012; 70:3-21.

10. Ludwig DS, Nestle M. Can the food industry play a constructive role in the obesity epidemic? JAMA 2008; 300:1808-11.

11. Rauber F, Campagnolo PD, Hoffman DJ, Vitolo MR. Consumption of ultraprocessed food products and its effects on children's lipid profiles: a longitudinal study. Nutr Metab Cardiovasc Dis 2015; 25:116-22.

12 Canella DS, Levy RB, Martins APB, Claro RM, Moubarac J-C, Baraldi LG, et al. Ultraprocessed food products and obesity in Brazilian Households (2008-2009). PLoS One 2014; 9:e92752.

13. Basu S, McKee M, Galea G, Stuckler, D. Relationship of soft drink consumption to global overweight, obesity, and diabetes: a crossnational analysis of 75 countries. Am J Public Health 2013; 103:2071-7.

14. Pan American Health Organization. Ultraprocessed food and drink products in Latin America: trends, impact on obesity, policy implications. Washington DC: Pan American Health Organization; 2015.

15. Moodie R, Stuckler D, Monteiro C, Sheron N, Neal B, Thamarangsi T, et al. Profits and pandemics: prevention of harmful effects of tobacco, alcohol, and ultraprocessed food and drink industries. Lancet 2013; 381:670-9. 
16. Hastings G, Stead M, McDermott L, Forsyth A, MacKintosh AM, Rayner M, et al. Review of research on the effects of food promotion to children. London: Food Standards Agency; 2003.

17. Institute of Medicine. Food marketing to children and youth: threat or opportunity? Washington DC: National Academies Press; 2006.

18. Mallarino C, Gómez LF, González-Zapata L, Cadena Y, Parra DC. Advertising of ultra-processed foods and beverages: children as a vulnerable population. Rev Saúde Pública 2013; 47:1006-10.

19. Letona P. Estudio exploratorio sobre la promoción y publicidad de alimentos y bebidas no saludables dirigidas a niños en América Latina y el Caribe. Ciudad de Panamá: United Nations Children's Fund; 2015.

20. Cairns G, Angus K, Hastings G. The extent, nature and effects of food promotion to children. A review of the evidence to december 2008 . Geneva: World Health Organization; 2009.

21. Han E, Powell LM, Kim TH. Trends in exposure to television food advertisements in South Korea. Appetite 2013; 62:225-31.

22. Hawkes C. Food packaging: the medium is the message. Public Health Nutr 2010; 13:297-9.

23. Moskowitz H, Reiner M, Lawlor JB, Deliza $\mathrm{R}$. Packaging research in food product design and development. Hoboken: Wiley-Blackwell; 2009.

24. Chacon V, Letona P, Barnoya J. Child-oriented marketing techniques in snack food packages in Guatemala. BMC Public Health 2013; 13:967-72.

25. Hebden L, King L, Kelly B, Chapman K, InnesHughes C. A menagerie of promotional characters: promoting food to children through food packaging. J Nutr Educ Behav 2011; 43:349-55.

26. Elliot C. Assessing 'fun foods': nutritional content and analysis of supermarket foods targeted at children. Obes Rev 2007; 9:368-77.

27. Roberto CA, Baik J, Harris JL, Brownell KD. Influence of licensed characters on children's taste and snack preferences. Pediatrics 2010; 126:88-93.

28. Elliot CD. Healthy food looks serious: how children interpret packaged food products. Canadian Journal of Communication 2009; 34:359-80.

29. Ferreira JSG, Silva Y, Moraes OMG, Tancredi RP. Marketing de alimentos industrializados destinados ao público infantil na perspectiva da rotulagem. Visa em Debate 2015; 3:75-84.

30. Pan American Health Organization. Pan American Health Organization nutrient profile model. Washington DC: Pan American Health Organization; 2016.

31. Harris JL, Schwartz MB, Brownell KD. Marketing foods to children and adolescents: licensed characters and other promotions on packaged foods in the supermarket. Public Health Nutr 2010; 13:409-17.
32. Chapman K, Nicholas P, Banovic D, Supramaniam $R$. The extent and nature of food promotion directed to children in Australian supermarkets. Health Promot Int 2006; 21:331-9.

33. Monteiro CA, Levy RB, Claro RM, Castro IR, Cannon G. Increasing consumption of ultraprocessed foods and likely impact on human health: evidence from Brazil. Public Health Nutr 2011; 14:5-13.

34. Ministerio de Salud Pública. Segunda encuesta nacional de factores de riesgo de enfermedades crónicas no transmisibles. Montevideo: Ministerio de Salud Pública; 2015.

35. Ülger B. Packages with cartoon trade characters versus advertising: An empirical examination of preschoolers' food preferences. J Food Products Market 2009; 15:104-17.

36. Lemish D. Children and television: a global perspective. Oxford: Blackwell; 2007.

37. Kotler JA, Schiffman JM, Hanson KG. The influence of media characters on children's food choices. J Health Commun 2012; 17:886-98.

38. De Droog SM, Valkenburg PM, Buijzen M. Using brand characters to promote young children's liking of and purchase requests for fruit. J Health Commun 2011; 16:79-89.

39. Hutchings JB. Expectations and the food industry: The impact of color and appearance. New York: Kluwer Academic/Plenum Publishers; 2003.

40. Ares G, Deliza R. Studying the influence of package shape and colour on consumer expectations of milk desserts using word association and conjoint analysis. Food Qual Prefer 2010; 21:930-7.

41. Slaughter V, Ting C. Development of ideas about food and nutrition from preschool to university. Appetite 2010; 55:556-64.

42. Soldavini J, Crawford P, Ritchie LD. Nutrition claims influence health perceptions and taste preferences in fourth- and fifth-grade children. J Nutr Educ Behav 2012; 44:624-7.

43. Abrams KM, Evans C, Duff BRL. Ignorance is bliss. How parents of preschool children make sense of front-of-package visuals and claims on food. Appetite 2015; 87:20-9.

44. Colby SE, Johnson L, Scheett A, Hoverson B. Nutrition marketing of food labels. J Nutr Educ Behav 2010; 42:92-8.

45. Food Standards Australia and New Zealand. Calculation method for determining foods eligible to make health claims: nutrient profiling calculator. http://www.foodstandards.gov. au/_srcfiles/method\%20to\%20determine\%20 eligibility\%20_final_.pdf (accessed on 18/May/ 2017).

46. Freeman B, Chapman S, Rimmer M. The case for the plain packaging of tobacco products. Addiction 2008; 103:580-90. 


\section{Resumo}

A publicidade de produtos alimentícios pouco saudáveis tem sido identificada como uma das principais características do ambiente alimentar com efeito negativo sobre a alimentação das crianças. Diversos países já impuseram restrições sobre a publicidade de produtos alimentícios pouco saudáveis para crianças. Entretanto, as estratégias publicitárias não se limitam à radiodifusão e às mídias digitais; incluem também o desenho das embalagens. Nesse contexto, o estudo buscou descrever os alimentos dirigidos ao público infantil e vendidos em supermercados em Montevidéu, Uruguai, em termos de desenho de embalagem e perfil de nutrientes. Dois supermercados em Montevidéu foram selecionados para a coleta dos dados. Em cada supermercado, foram identificados todos os produtos dirigidos ao público infantil. Os produtos foram analisados quanto ao desenho da embalagem e perfil nutricional, considerando o Modelo de Perfil de Nutrientes da Organização Pan -Americana da Saúde. Foi identificado um total de 180 produtos, incluindo uma ampla variedade de categorias de produtos. A grande maioria dos produtos correspondia aos ultra-processados, com teores excessivos de sódio, açucares livres, gordura total e gordura saturada e/ou trans, que são contraindicados para consumo frequente. Foram identificadas diversas estratégias mercadológicas no desenho das embalagens para atrair a atenção das crianças e moldar suas preferências. As estratégias mais comuns foram a inclusão de personagens de desenho animado, cores brilhantes, letras infantilizadas e uma ampla gama de alegações em relação à saúde e nutrição e às características sensoriais e hedônicas dos produtos Os achados do estudo fornecem evidências adicionais sobre a necessidade de regulamentar as embalagens dos produtos alimentícios para crianças.

Embalagem de Alimentos; Composição de Alimentos; Publicidade de Alimentos; Criança

\section{Resumen}

El marketing de productos poco saludables se ha identificado como una de las características del entorno alimentario que afecta negativamente los hábitos alimentarios de los niños. Diferentes países han impuesto restricciones a la publicidad de alimentos poco saludables dirigidos a niños. Sin embargo, las estrategias de marketing no se limitan a la publicidad visual y digital, sino que también incluyen el diseño de envases. En este contexto, el presente estudio tuvo como objetivo describir los productos alimenticios dirigidos a niños y vendidos en supermercados de Montevideo, Uruguay, en términos de diseño del envase y perfil nutricional. Se seleccionarondos supermercados em Montevideo para la recollección de datos. En cada supermercado, se identificaron todos los productos dirigidos a niños. Se analizaron los productos en términos de diseño del envase y perfil nutrientes, considerando el Modelo de Perfil Nutricional de la Organización Panamericana de la Salud. Se identificaron un total de 180 productos, que incluyeron una amplia variedad de categorías. La gran mayoría de los productos correspondieron a productos ultraprocesados con excesivas cantidades de sodio, azúcares, grasa total, grasas saturadas, y/o grasas trans, cuyo consumo frecuente no está recomendado. Se identificaron diversas estrategias de marketing en el envase de los productos para atraer la atención de los niños e influenciar sus preferencias. Las estrategias más comunes fueron la inclusión de personajes de infantiles, colores vivos, letras infantiles y una amplia variedad de alegaciones sobre salud y nutrición, así como relacionadas con caracteriticas sensoriales y hedónicas de los productos. Los hallazgos del estudio proporcionan evidencias adicionales sobre la necesidad de regular el diseño de los envases de los productos dirigidos a niños.

Embalaje de Alimentos; Composición de Alimentos; Publicidad de Alimentos; Niño
Submitted on $29 / \mathrm{Fev} / 2016$

Final version resubmitted on $04 / \mathrm{Jul} / 2016$

Approved on 18/Jul/2016 